\title{
Efficacy and Metabolizable Energy Equivalence of an $\alpha$-Amylase- $\beta$-Glucanase Complex for Broilers
}

http://dx.doi.org/10.1590/1516-635x1702227-236

\section{-Author(s)}

Vieira SL'

Stefanello $\mathrm{C}^{\prime}$

Rios HV'

Serafini $N^{\prime}$

Hermes RG"

Sorbara JOB"

Departamento de Zootecnia, Universidade Federal do Rio Grande do Sul, Avenida Bento Gonçalves, 7712, Porto Alegre, RS, Brazil 91540-000

" DSM Nutritional Products, Av. Eng. Billings, 1729, São Paulo, SP, Brazil 05321-900

\section{-Mail Address}

Corresponding author e-mail address Vieira S.L.

Departamento de Zootecnia, Universidade Federal do Rio Grande do Sul

Avenida Bento Gonçalves, 7712, Porto

Alegre, RS, 91540-000, Brazil

Phone/FAX: 555133086048

E-mail: slvieira@ufrgs.br

\section{-Keywords}

$\alpha$-amylase, carbohydrases, enzyme.

\section{ABSTRACT}

A trial was conducted to evaluate the effects of adding an exogenous $\alpha$-amylase- $\beta$-glucanase complex produced from Bacillus amyloliquefaciens on the growth performance, carcass yield, and relative AME bioequivalence in broilers fed corn-soy diets from 1 to 40 $\mathrm{d}$ of age. One thousand seven hundred and fifty one-day-old Cobb $x$ Cobb 500 slow-feathering male broilers were randomly allotted to seven treatments with 10 replicates of 25 birds each as follows: control diet (C); C diet with reduction of 60 (C-60), 90 (C-90), or 120 (C-120) kcal $\mathrm{AME} / \mathrm{kg}$; C diet with reduction of $120 \mathrm{kcal} \mathrm{AME} / \mathrm{kg}$ and supplemented with 200 (C-120-200), 300 (C-120-300), or 400 (C-120-400) mg of the enzyme complex $/ \mathrm{kg}$. Each g of the enzyme complex corresponded to 200 kilo-Novo $\alpha$-amylase and 350 fungal $\beta$-glucanase units. On $d$ 40 , eight birds were randomly taken from each pen and processed to evaluate carcass and commercial cuts yields. Percent mortality was not affected by the treatments $(p>0.05)$. Live performance, as indicated by BW gain (BWG) linearly decreased $(p<0.05)$ and FCR linearly increased with the reduction in AME. Birds fed diets supplemented with the enzyme complex showed weekly improvements in BWG and FCR. There were no effects of the treatments on the yield of the carcass or of commercial cuts; however, abdominal fat was significantly lower ( $p$ $<0.0343$ ) in birds fed the $\mathrm{C}-120-400$ compared to the $\mathrm{C}-120$ feeding program (1.67\% vs. $1.90 \%)$; all other treatments were intermediate. Average AME equivalence of the enzyme complex varied weekly. Estimations for the entire period were 40, 46, and $56 \mathrm{kcal}$ for BWG and 58,76 , and $99 \mathrm{kcal}$ AME/ $\mathrm{kg}$ for FCR $(p<0.001)$ for the diets containing 200,300 , and $400 \mathrm{mg}$ enzyme complex/kg, respectively.

\section{INTRODUCTION}

Studies evaluating the use of supplemental enzymes in poultry diets have presented a substantial increase in the last years. A wide variety of enzyme types targeting diverse substrates have been used in these studies, which include mono-component enzyme products with only one enzymatic activity and others having more than one enzyme.

Results from enzyme supplementation studies vary with the many circumstances involved in their evaluation, but having a target substrate in the feed is essential so that enzyme action can lead to an amount of released product that could be directly or indirectly measured through the evaluation of metabolism assays or animal performance (Olukosi \& Adeola, 2008; Jozefiak et al., 2010). It has been demonstrated that dietary supplementation of xylanase and glucanase improves the performance and nutrient digestibility of broilers fed diets containing high levels of grains rich in non-starch polysaccharides (NSP) (Gracia et al., 2003), which have been frequently related to a decrease in intestinal viscosity (Petterson et al., 1991; Lázaro et al., 2003). However, 
total NSP content in corn and soy are low compared to wheat and barley, for instance (Willamil et al., 2012), and therefore, diets having large proportions of corn are not expected to present important viscosity-related problems.

The post-hatching chick needs to adapt from maternal nutrition to exogenous feed, when nutrient supply changes from the high fat yolk sac to a high starch feed, and this process may take several days (Vieira \& Moran, 1999). During this period, the secretion of endogenous enzymes also changes according to the composition of the exogenous feed, together with an increase in digestive organ size to rapidly accommodate the increase in feed intake (Noy \& Sklan, 1995). Starch is the substrate that proportionally increases the most in corn-soy diets as birds age; therefore, amounts of secreted amylase may limit energy available for growth. The secretion of amylase seems to quickly stabilize even though starch intake is increased with time. Amylase secretion is low at $4 \mathrm{~d}$ of age (Noy \& Sklan, 1995); however, increases in its pancreatic secretion seem to flatten between 7 to 21 d (Noy \& Sklan, 1995; Uni et al., 1995). The benefits of a $\beta$-glucanase in corn-soy diets are expected to be lower than in wheat- and barley-based diets due to a much smaller proportion of its substrate in that type of feed; however, there are few studies with this type of enzyme in corn-soy diets (Leslie et al., 2007; Rutherfurd et al., 2007; Cowieson et al., 2010). It may be possible that the association with $\alpha$-amylase could render measurable improvements when fed to broilers.

Performance and diet digestibility improvements were observed when blends of amylase, proteases, and xylanases were added to corn-soy diets (Zanella et al., 1999; Douglas et al., 2000; Café et al., 2002). Gracia et al. (2003) reported positive digestibility and performance effects when including a mono-component $\alpha$-amylase from Bacillus amyloliquefaciens. Similarly, Onderci et al. (2006) reported improvements in gut morphology, digestibility, and performance when birds were fed an $\alpha$-amylase from Bacillus stearothermophilus. Enzyme supplementation with an enzyme blend containing $\alpha$-amylase, $\beta$-glucanase, and xylanase increased the AME content of a corn-soy diet as well as the apparent and true ileal amino acid digestibility for all amino acids (Rutherfurd et al., 2007).

The objective of the present study was to evaluate the effects of increasing supplementation levels of a commercial $\alpha$-amylase- $\beta$-glucanase complex derived from Bacillus amyloliquefaciens fermentation on the growth performance and carcass and commercial cuts yields of broilers fed corn-soy diets from 1 to $40 \mathrm{~d}$ of age. An estimation of the equivalence in AME of this enzyme complex is also proposed.

\section{MATERIALS AND METHODS}

All procedures used in this study avoided unnecessary animal distress and were approved by the Ethics and Research Committee of Universidade Federal do Rio Grande do Sul, Porto Alegre, Brazil.

\section{Broiler husbandry}

A total of 1750 one-day-old Cobb $\times$ Cobb 500 slowfeathering male broiler chicks, vaccinated for Marek's disease, were obtained from a commercial hatchery and randomly assigned to seven treatments with 10 replicates of 25 birds each distributed in 70 floor pens measuring $1.65 \times 1.65 \mathrm{~m}$ (9.18 birds per $\mathrm{m}^{2}$ ). Chick average weight was $45 \pm 1 \mathrm{~g}$ at placement. Birds were housed in an open-sided broiler house with rice-hulls litter. Each pen was equipped with three water nipples and one $18-\mathrm{kg}$ tube feeder.

Average house temperature was $32^{\circ} \mathrm{C}$ at placement and was maintained within a range to optimize animal comfort using heaters, fans, and foggers, when appropriate. Lighting was continuous until $\mathrm{d} 7$ and a 16:8 h L:D schedule used thereafter until d 40. Feed and water were available for ad libitum consumption.

\section{Experimental diets}

Diets were based on corn and soybean meal and were formulated to meet or exceed the birds' nutrient and energy requirements (Rostagno et al., 2011), with the exception of AME. Mash diets were fed in a 4-phase feeding program as follows: pre-starter ( 1 to 7), starter (d 8 to 21), grower (d 22 to 35), and finisher (d 36 to 40). Diets are presented on Tables 1 and 2 . Dietary treatments were formulated for the pre-starter, starter, grower, and finisher phases: a control diet (C) with 2,950; 3,050; 3,100 and 3,150 kcal/kg of AME, respectively, and three corresponding reductions of 60 (C-60), 90 (C-90) and 120 (C-120) kcal AME/kg in all feeds.

The enzyme complex was supplemented to the diets with $120 \mathrm{kcal}$ AME/kg reduction at 200 (C120-200), 300 (C-120-300) and 400 (C-120-400) $\mathrm{mg} / \mathrm{kg}$ of an exogenous $\alpha$-amylase $+\beta$-glucanase complex (Ronozyme A, Novozymes S/A, Bagsvaerd, Denmark). The $\alpha$-amylase $+\beta$-glucanase complex used is a granulated enzyme preparation produced by submerged fermentation of Bacillus amyloliquefaciens. 
Each gram of the enzyme product corresponds to 200 kilo-Novo $\alpha$-amylase units and 350 fungal $\beta$-glucanase units. The activity of one kilo-Novo $\alpha$-amylase unit is defined as the amount of enzyme that hydrolyzes 1 mg of soluble starch at $60^{\circ} \mathrm{C}$ at $\mathrm{pH} 6.0$, per minute, whereas one fungal $\beta$-glucanase unit is the amount of enzyme that releases glucose or other reducing carbohydrates with a reduction power corresponding to $1 \mu \mathrm{mol}$ glucose per minute at $30^{\circ} \mathrm{C}$ and $\mathrm{pH} 5.0$ (Rutherfurd et al., 2007).

\section{Measurements}

Live performance was evaluated through weekly measurements of BW gain (BWG), feed intake ( $\mathrm{FI})$, and FCR corrected for the weight of dead birds from 1 to $40 \mathrm{~d}$ of age. At the end of the study birds were processed for evaluation of carcass yield as follows. Eight birds per pen $(n=560)$ were randomly selected, fasted for $8 \mathrm{~h}$, and individually weighed previously to processing. Birds were then electrically stunned with $45 \mathrm{~V}$ for $3 \mathrm{~s}$ and then bled for 3 min after a jugular vein cut. Carcasses were scalded at $60^{\circ} \mathrm{C} 45 \mathrm{~s}$, and the feathers being immediately mechanically plucked, manually eviscerated, and statically chilled in slush ice for approximately $3 \mathrm{~h}$. The eviscerated carcasses (without feet and neck but with lungs) were hung for 3 min to remove excess water prior to their individual weighing; abdominal fat was weighed separately.

Table 1 - Broiler pre-starter ( 1 to $7 \mathrm{~d}$ ) and starter (8 to $21 \mathrm{~d}$ ) diets with graded AME reductions and supplemented or not with $\alpha$-amylase $+\beta$-glucanase complex.

\begin{tabular}{|c|c|c|c|c|c|c|c|c|}
\hline \multirow[t]{2}{*}{ Ingredients, \% } & \multicolumn{4}{|c|}{ Pre-starter } & \multicolumn{4}{|c|}{ Starter } \\
\hline & Control (C) & C - $60 \mathrm{kcal}$ & C - $90 \mathrm{kcal}$ & C - $120 \mathrm{kcal}$ & Control (C) & C - $60 \mathrm{kcal}$ & C - $90 \mathrm{kcal}$ & C - $120 \mathrm{kcal}$ \\
\hline Corn $7.5 \%$ & 50.12 & 51.53 & 52.22 & 52.84 & 56.44 & 57.87 & 58.57 & 59.20 \\
\hline Soybean meal $45 \%$ & 41.54 & 41.28 & 41.16 & 41.04 & 35.10 & 34.84 & 34.72 & 34.60 \\
\hline Soybean oil & 3.69 & 2.53 & 1.96 & 1.41 & 3.92 & 2.76 & 2.18 & 1.63 \\
\hline Dicalcium phosphate & 1.88 & 1.88 & 1.88 & 1.88 & 1.84 & 1.83 & 1.83 & 1.83 \\
\hline Limestone & 1.27 & 1.27 & 1.27 & 1.27 & 1.23 & 1.23 & 1.23 & 1.24 \\
\hline Salt & 0.65 & 0.65 & 0.65 & 0.65 & 0.46 & 0.46 & 0.46 & 0.45 \\
\hline L-lysine HCL 78\% & 0.17 & 0.17 & 0.17 & 0.18 & 0.19 & 0.19 & 0.19 & 0.19 \\
\hline DL-methionine 99\% & 0.33 & 0.33 & 0.33 & 0.33 & 0.28 & 0.28 & 0.28 & 0.28 \\
\hline L-threonine $98.5 \%$ & 0.05 & 0.05 & 0.05 & 0.05 & 0.05 & 0.05 & 0.05 & 0.05 \\
\hline Sodium Bicarbonate & 0.04 & 0.05 & 0.05 & 0.05 & 0.20 & 0.20 & 0.20 & 0.20 \\
\hline Vitamin mineral mix ${ }^{1}$ & 0.20 & 0.20 & 0.20 & 0.20 & 0.20 & 0.20 & 0.20 & 0.20 \\
\hline Choline chloride $60 \%$ & 0.06 & 0.06 & 0.06 & 0.06 & 0.09 & 0.09 & 0.09 & 0.09 \\
\hline Kaolin (inert material) & --- & --- & --- & 0.04 & --- & - -- $^{-1}$ & --- & 0.04 \\
\hline Enzyme $^{2}$ & --- & --- & --- & --- & --- & --- & --- & --- \\
\hline Total & 100.00 & 100.00 & 100.00 & 100.00 & 100.00 & 100.00 & 100.00 & 100.00 \\
\hline \multicolumn{9}{|c|}{ Energy and nutrients, $\%$ or as noted } \\
\hline AME, $\mathrm{kcal} / \mathrm{kg}$ & 2,950 & 2,890 & 2,860 & 2,830 & 3,050 & 2,990 & 2,960 & 2,930 \\
\hline$C P$ & 23.32 & 23.32 & 23.32 & 23.32 & 20.91 & 20.91 & 20.91 & 20.91 \\
\hline Digestible Lys & 1.28 & 1.28 & 1.28 & 1.28 & 1.15 & 1.15 & 1.15 & 1.15 \\
\hline Digestible TSAA & 0.96 & 0.96 & 0.96 & 0.96 & 0.86 & 0.86 & 0.86 & 0.86 \\
\hline Digestible Thr & 0.83 & 0.83 & 0.83 & 0.83 & 0.75 & 0.75 & 0.75 & 0.75 \\
\hline $\mathrm{Ca}$ & 1.00 & 1.00 & 1.00 & 1.00 & 0.96 & 0.96 & 0.96 & 0.96 \\
\hline Av.P & 0.50 & 0.50 & 0.50 & 0.50 & 0.48 & 0.48 & 0.48 & 0.48 \\
\hline $\mathrm{Na}$ & 0.23 & 0.23 & 0.23 & 0.23 & 0.21 & 0.21 & 0.21 & 0.21 \\
\hline Starch ${ }^{3}$ & 31.83 & 32.72 & 33.16 & 33.55 & 35.84 & 36.75 & 37.20 & 37.59 \\
\hline
\end{tabular}

'Provided the following per kilogram of diet: vitamin $\mathrm{A}, 9,000 \mathrm{IU}$; vitamin $\mathrm{D}_{3}, 2,500 \mathrm{IU}$; vitamin $\mathrm{E}, 100 \mathrm{IU}$; vitamin $\mathrm{K}_{3}, 2.5 \mathrm{mg}$; vitamin $\mathrm{B}_{12}$, $12 \mu \mathrm{m}$; thiamine, $1,5 \mathrm{mg}$; riboflavin, $6 \mathrm{mg}$; vitamin $B_{6}, 3$ mg; niacin, $25 \mathrm{mg}$; pantothenic acid, $12 \mathrm{mg}$; folic acid, $8 \mathrm{mg}$; biotin, $0.3 \mathrm{mg}$; selenium, $0.25 \mathrm{mg}$; iron, $100 \mathrm{mg}$; zinc, $100 \mathrm{mg}$; manganese, $160 \mathrm{mg}$; copper, 20 ppm; iodine, $2 \mathrm{mg}$; cobalt, $2 \mathrm{mg}$; Monensin sodium $110 \mathrm{ppm}$.

${ }^{2} \alpha$-amylase $+\beta$-glucanase complex produced by Bacillus amyloliquefaciens having a minimum activity of 200 kilo-Novo $\alpha$-amylase units and 350 fungal $\beta$-glucanase units per gram obtained from Novozymes A/S (Bagsvaerd, Denmark).

${ }^{3}$ Estimated from FEDNA (2003). 
Table 2 - Broiler grower (22 to $35 \mathrm{~d}$ ) and finisher (36 to $42 \mathrm{~d}$ ) diets with graded AME reductions and supplemented or not with an $\alpha$-amylase $+\beta$-glucanase complex.

\begin{tabular}{|c|c|c|c|c|c|c|c|c|}
\hline \multirow[t]{2}{*}{ Ingredients, \% } & \multicolumn{4}{|c|}{ Grower } & \multicolumn{4}{|c|}{ Finisher } \\
\hline & Control (C) & C - $60 \mathrm{kcal}$ & C - $90 \mathrm{kcal}$ & C - $120 \mathrm{kcal}$ & Control (C) & C - $60 \mathrm{kcal}$ & C - $90 \mathrm{kcal}$ & C - $120 \mathrm{kcal}$ \\
\hline Corn $7.5 \%$ & 60.03 & 61.43 & 62.14 & 62.76 & 65.45 & 66.87 & 67.58 & 68.19 \\
\hline Soybean meal 45\% & 31.76 & 31.51 & 31.38 & 31.27 & 26.84 & 26.58 & 26.45 & 26.34 \\
\hline Soybean oil & 3.98 & 2.83 & 2.25 & 1.70 & 3.76 & 2.60 & 2.02 & 1.47 \\
\hline Dicalcium phosphate & 1.70 & 1.70 & 1.70 & 1.70 & 1.51 & 1.51 & 1.51 & 1.51 \\
\hline Limestone & 1.22 & 1.22 & 1.22 & 1.22 & 1.17 & 1.17 & 1.17 & 1.17 \\
\hline Salt & 0.44 & 0.44 & 0.44 & 0.44 & 0.40 & 0.40 & 0.40 & 0.40 \\
\hline L-lysine HCL 78\% & 0.20 & 0.20 & 0.21 & 0.21 & 0.22 & 0.22 & 0.22 & 0.23 \\
\hline DL-methionine 99\% & 0.26 & 0.26 & 0.25 & 0.25 & 0.23 & 0.23 & 0.23 & 0.23 \\
\hline L-threonine $98.5 \%$ & 0.03 & 0.03 & 0.03 & 0.03 & 0.03 & 0.03 & 0.03 & 0.03 \\
\hline Sodium Bicarbonate & 0.08 & 0.08 & 0.08 & 0.08 & 0.09 & 0.09 & 0.09 & 0.09 \\
\hline Vitamin mineral mix & 0.20 & 0.20 & 0.20 & 0.20 & 0.20 & 0.20 & 0.20 & 0.20 \\
\hline Choline chloride $60 \%$ & 0.10 & 0.10 & 0.10 & 0.10 & 0.10 & 0.10 & 0.10 & 0.10 \\
\hline Kaolin (inert material) & --- & --- & --- & 0.04 & --- & --- & --- & 0.04 \\
\hline Enzyme $^{2}$ & --- & --- & --- & --- & --- & --- & --- & --- \\
\hline Total & 100.00 & 100.00 & 100.00 & 100.00 & 100.00 & 100.00 & 100.00 & 100.00 \\
\hline \multicolumn{9}{|c|}{ Energy and nutrients, $\%$ or as noted } \\
\hline AME, $\mathrm{kcal} / \mathrm{kg}$ & 3,100 & 3,040 & 3,010 & 3,010 & 3,150 & 3,090 & 3,060 & 3,030 \\
\hline$C P$ & 19.67 & 19.67 & 19.67 & 19.67 & 17.87 & 17.87 & 17.87 & 17.87 \\
\hline Digestible Lys & 1.08 & 1.08 & 1.08 & 1.08 & 0.98 & 0.98 & 0.98 & 0.98 \\
\hline Digestible TSAA & 0.81 & 0.81 & 0.81 & 0.81 & 0.75 & 0.75 & 0.75 & 0.75 \\
\hline Digestible Thr & 0.68 & 0.68 & 0.68 & 0.68 & 0.61 & 0.61 & 0.61 & 0.61 \\
\hline $\mathrm{Ca}$ & 0.92 & 0.92 & 0.92 & 0.92 & 0.85 & 0.85 & 0.85 & 0.85 \\
\hline Av.P & 0.44 & 0.44 & 0.44 & 0.44 & 0.40 & 0.40 & 0.40 & 0.40 \\
\hline $\mathrm{Na}$ & 0.20 & 0.20 & 0.20 & 0.20 & 0.18 & 0.18 & 0.18 & 0.18 \\
\hline
\end{tabular}

38.12

39.01

39.46

39.85

41.56

42.46

42.91

43.30

'Vitamin, trace minerals, and growth promoters provided the following per kilogram of diet: vitamin A, 9,000 IU; vitamin $\mathrm{D}_{3^{\prime}} 2,500 \mathrm{IU}$; vitamin $\mathrm{E}, 100 \mathrm{IU} ;$ vitamin $\mathrm{K}_{3}, 2.5 \mathrm{mg}$; vitamin $\mathrm{B}_{12}, 12 \mathrm{\mu g}$; thiamine, 1,5 mg; riboflavin, $6 \mathrm{mg}$; vitamin $\mathrm{B}_{6^{\prime}} 3 \mathrm{mg}$; niacin, $25 \mathrm{mg}$; pantothenic acid, $12 \mathrm{mg}$; folic acid, $8 \mathrm{mg}$; biotin, $0.3 \mathrm{mg}$; selenium, $0.25 \mathrm{mg}$; iron, $100 \mathrm{mg}$; zinc, 100 mg; manganese, $160 \mathrm{mg}$; copper, 20 ppm; iodine, 2 mg; cobalt, 2 mg; Monensin Sodium 110 ppm.

${ }^{2} \alpha$-amylase $+\beta$-glucanase complex is produced by Bacillus amyloliquefaciens having a minimum activity of 200 kilo-Novo $\alpha$-amylase units and 350 fungal $\beta$-glucanase units per gram obtained from Novozymes A/S (Bagsvaerd, Denmark).

${ }^{3}$ Estimated from FEDNA (2003).

Carcass yield was expressed relative to live weight, whereas commercial cuts and abdominal fat were expressed as a proportion of carcass weight.

\section{Statistical analysis}

Data were analyzed as a one-way analysis of variance using the GLM procedure of SAS (2009). Significance was accepted at $5 \%$ and mean differences were separated using the test of Tukey when the model effect was significant (Tukey, 1991). Linear and quadratic effects of decreasing AME were tested for the diets not supplemented with the enzyme. The corresponding AME for obtained BWG and FCR at each enzyme supplemental inclusion levels allowed estimations of added improvements in AME provided by the enzyme complex at any point of the curve. The regression equations of AME level intake and supplemental amylase intake (based on formulated values) for a particular response variable were equated and solved for $x$ in quadratic or linear equations. Calculation of enzyme equivalence utilized in the present study followed the methodology reported by Adedokun et al. (2004) and Jendza et al. (2006), who estimated $P$ equivalence from phytase.

\section{RESULTS AND DISCUSSION}

The analysis of the added enzyme complex in the experimental feeds showed that concentrations of $\alpha$-amylase and $\beta$-glucanase were as expected 
(formulated: 40,60 , and 80 kilo-Novo $\alpha$-amylase units/ kg; analyzed: 42, 63, and 85 kilo-Novo $\alpha$-amylase units $/ \mathrm{kg}$, respectively).

Treatments affected BWG $(p<0.05)$ and FCR ( $p$ $<0.05$ ) of birds throughout all the evaluated weeks with performance losses as AME was reduced, but there were partial compensations by the enzyme supplementation (Table 3). Table 4 shows that BWG and FCR linearly fit to AME reductions in the diets without enzyme supplementation ( $p<0.05)$, but no effects were observed on feed intake in all weekly evaluations. Figures 1 and 2 show the linear adjustments for BWG and FCR obtained from placement to the end of the study when birds were fed the different enzyme dietary concentrations. There were no effects of the treatments on mortality (overall grand mean was 3.52\%).

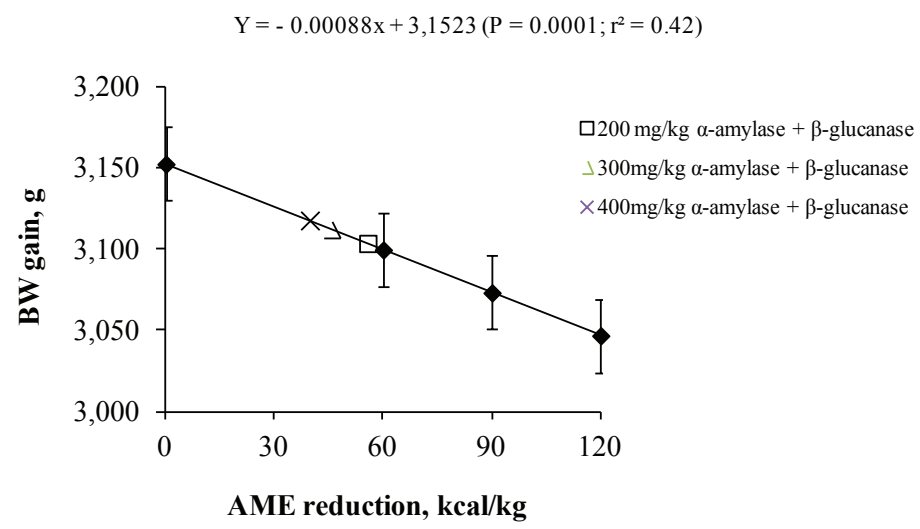

Figure 1 - BW gain of broilers fed diets with decreasing AME levels supplemented or not with an $\alpha$-amylase $+\beta$-glucanase complex from 1 to $40 \mathrm{~d}$, $\mathrm{g}$.

$\mathrm{Y}=0.00039 \mathrm{x}+1.6035\left(\mathrm{P}=0.0003 ; \mathrm{r}^{2}=0.29\right)$

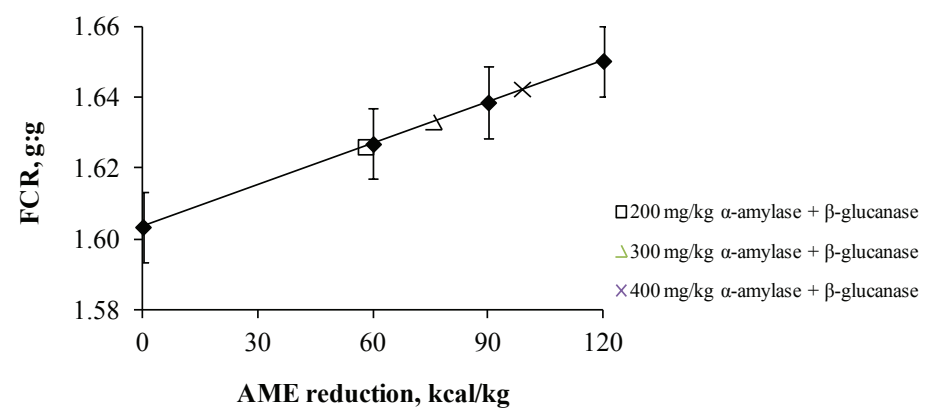

Figure 2 - Feed conversion ratio of broilers fed diets with decreasing AME levels supplemented or not with an $\alpha$-amylase $+\beta$-glucanase complex from 1 to $40 \mathrm{~d}$.

There were no effects of the treatments on carcass and commercial cuts yields. However, abdominal fat as proportion of the eviscerated carcass was significantly lower $(p<0.0343)$ in birds fed the $C-120-400$ compared with the C-120 feeding program (1.67\% vs. $1.90 \%)$; all other treatments were intermediate (Table 5).
Apparent metabolizable energy equivalence was calculated using BWG and FCR of the birds fed the different enzyme levels compared with the responses obtained as AME was reduced in diets without enzyme supplementation. These equivalences varied with age and enzyme concentration in the feed, reaching the lowest values in the first week and highest in the fourth. Average AME equivalence for the enzyme complex varied weekly. Estimations for the entire period were 40, 46, and $56 \mathrm{kcal}$ for BWG and 58, 76, and $99 \mathrm{kcal}$ AME/kg for FCR when birds were fed 200, 300, and $400 \mathrm{mg} / \mathrm{kg}$ of the enzyme complex, respectively. Data for each week is presented on Table 4.

Research on the use of exogenous enzymes for broilers has been ongoing for decades; however, its commercial use is more recent. The practical use of phytase in chicken diets is presently well established in the commercial environment, but the use of enzymes targeting other substrates is less frequent. This is rapidly changing because of the increases in ingredient costs, especially those that supply energy because of their market connections with biofuels.

A diversity of explanations has been used to try to explain the improvements obtained using exogenous carbohydrases in poultry nutrition, and they are not always related to a greater degradation of the target substrate of these enzymes. Obviously, improvements in AME obtained with broilers fed cornsoy diets supplemented with amylases are immediately attributed to greater starch breakdown, and therefore, greater starch digestibility. However, the effects on AME improvements in broilers may also be related to the breakdown of non-starch polysaccharides and protein that can result from the supplementation with other enzymes (Zhou et al., 2009).

The exposure of complex substrates (bearing different types of molecules) after their partial or total breakdown by the action of an enzyme can allow the access of other enzymes that otherwise would not be able to react with the original substrate. Therefore, degradation of a newly-presented substrate is frequently referred to explain these improvements (Cowieson et al., 2010). Part of the plant nutrients, such as starch and protein, are trapped within the insoluble cell walls (this is sometimes referred as cage effect) such that poultry are unable to access these nutrients (Englyst, 1989). Also, soluble fibers dissolve in the gut, forming viscous gels that trap nutrients and slow down rates of digestion and feed rate passage through the gut (Bedford et al., 1991; Veldman et al., 1994). 
Table 3 - Performance of broilers fed diets with graded AME reductions and supplemented or not with an $\alpha$-amylase + $\beta$-glucanase complex from d 1 to 40 .

\begin{tabular}{|c|c|c|c|c|c|c|c|c|}
\hline \multirow[t]{2}{*}{ Treatments } & \multirow[t]{2}{*}{ Enzyme, mg/kg² } & \multicolumn{7}{|c|}{ BWG, g } \\
\hline & & $1-7 d$ & $8-14 d$ & $15-21 d$ & $22-28 d$ & $29-35 d$ & $36-40 d$ & $1-40 d$ \\
\hline Control (C) & - & $120^{a}$ & $296^{a}$ & $524^{a}$ & $657^{a}$ & $851^{\mathrm{a}}$ & $707^{a}$ & $3,155^{a}$ \\
\hline $\mathrm{C}-60 \mathrm{kcal} / \mathrm{kg}$ & - & $118^{b}$ & $282^{\mathrm{b}}$ & $513^{b}$ & $641^{\mathrm{b}}$ & $842^{b}$ & $701^{\mathrm{ab}}$ & $3,097^{c}$ \\
\hline $\mathrm{C}-90 \mathrm{kcal} / \mathrm{kg}$ & - & $116^{b}$ & $283^{b}$ & $508^{c}$ & $639^{b c}$ & $827^{c}$ & $695^{b}$ & $3,068^{d}$ \\
\hline $\mathrm{C}-120 \mathrm{kcal} / \mathrm{kg}$ & - & $113^{c}$ & $285^{\mathrm{ab}}$ & $501^{d}$ & $633^{c}$ & $826^{c}$ & $694^{b}$ & $3,052^{e}$ \\
\hline $\mathrm{C}-120 \mathrm{kcal} / \mathrm{kg}$ & 200 & $120^{a}$ & $287^{\mathrm{ab}}$ & $513^{b}$ & $637^{b c}$ & $836^{b}$ & $711^{\mathrm{a}}$ & $3,103^{\mathrm{bc}}$ \\
\hline $\mathrm{C}-120 \mathrm{kcal} / \mathrm{kg}$ & 300 & $120^{\mathrm{a}}$ & $292^{\mathrm{ab}}$ & $514^{b}$ & $636^{\mathrm{bc}}$ & $837^{b}$ & $712^{\mathrm{a}}$ & $3,111^{b c}$ \\
\hline $\mathrm{C}-120 \mathrm{kcal} / \mathrm{kg}$ & 400 & $120^{a}$ & $294^{\mathrm{ab}}$ & $513^{b}$ & $639^{b c}$ & $841^{b}$ & $710^{a}$ & $3,117^{b}$ \\
\hline SEM $^{1}$ & & 0.70 & 1.22 & 1.70 & 2.36 & 3.36 & 3.14 & 6.21 \\
\hline$P$-value & & 0.0412 & 0.0042 & 0.0211 & 0.0171 & 0.0375 & 0.0493 & 0.0095 \\
\hline \multirow[t]{2}{*}{ Treatments } & Enzyme, mg/kg & \multicolumn{7}{|c|}{ Feed Intake, g } \\
\hline & & $1-7 d$ & $8-14 d$ & $15-21 d$ & $22-28 d$ & $29-35 d$ & $36-40 d$ & $1-40 d$ \\
\hline Control (C) & - & 130 & 395 & 725 & 1,062 & 1,401 & 1,343 & 5,056 \\
\hline $\mathrm{C}-60 \mathrm{kcal} / \mathrm{kg}$ & - & 131 & 394 & 735 & 1,067 & 1,399 & 1,355 & 5,081 \\
\hline $\mathrm{C}-90 \mathrm{kcal} / \mathrm{kg}$ & - & 126 & 396 & 730 & 1,052 & 1,381 & 1,344 & 5,029 \\
\hline $\mathrm{C}-120 \mathrm{kcal} / \mathrm{kg}$ & - & 126 & 395 & 721 & 1,050 & 1,384 & 1,345 & 5,021 \\
\hline $\mathrm{C}-120 \mathrm{kcal} / \mathrm{kg}$ & 200 & 131 & 399 & 736 & 1,065 & 1,399 & 1,365 & 5,095 \\
\hline $\mathrm{C}-120 \mathrm{kcal} / \mathrm{kg}$ & 300 & 129 & 403 & 735 & 1,060 & 1,394 & 1,361 & 5,082 \\
\hline $\mathrm{C}-120 \mathrm{kcal} / \mathrm{kg}$ & 400 & 129 & 400 & 729 & 1,059 & 1,394 & 1,357 & 5,068 \\
\hline SEM & & 1.94 & 3.35 & 3.18 & 6.62 & 9.54 & 8.82 & 22.76 \\
\hline$P$-value & & 0.3431 & 0.2112 & 0.5791 & 0.9861 & 0.8586 & 0.9427 & 0.9999 \\
\hline \multirow[t]{2}{*}{ Treatments } & \multirow[t]{2}{*}{ Enzyme, mg/kg } & \multicolumn{7}{|c|}{$\mathrm{FCR}^{3}$} \\
\hline & & $1-7 d$ & $8-14 d$ & $15-21 d$ & $22-28 d$ & $29-35 d$ & $36-40 d$ & $1-40 d$ \\
\hline Control (C) & - & $1.080^{c}$ & $1.336^{d}$ & $1.383^{\mathrm{d}}$ & $1.617^{d}$ & $1.646^{c}$ & $1.900^{c}$ & $1.602^{\mathrm{d}}$ \\
\hline $\mathrm{C}-60 \mathrm{kcal} / \mathrm{kg}$ & - & $1.114^{\mathrm{a}}$ & $1.396^{\mathrm{ab}}$ & $1.433^{\mathrm{ab}}$ & $1.665^{\mathrm{ab}}$ & $1.661^{\mathrm{ab}}$ & $1.933^{\mathrm{ab}}$ & $1.641^{\mathrm{ab}}$ \\
\hline $\mathrm{C}-90 \mathrm{kcal} / \mathrm{kg}$ & - & $1.087^{b c}$ & $1.399^{a}$ & $1.437^{\mathrm{ab}}$ & $1.646^{c}$ & $1.670^{\mathrm{ab}}$ & $1.934^{\mathrm{ab}}$ & $1.639^{b c}$ \\
\hline $\mathrm{C}-120 \mathrm{kcal} / \mathrm{kg}$ & - & $1.119^{\mathrm{a}}$ & $1.386^{\mathrm{b}}$ & $1.439^{a}$ & $1.659^{\mathrm{abc}}$ & $1.676^{a}$ & $1.938^{\mathrm{a}}$ & $1.645^{\mathrm{a}}$ \\
\hline $\mathrm{C}-120 \mathrm{kcal} / \mathrm{kg}$ & 200 & $1.096^{b}$ & $1.392^{\mathrm{a}}$ & $1.434^{\mathrm{ab}}$ & $1.672^{\mathrm{a}}$ & $1.674^{\mathrm{a}}$ & $1.922^{b}$ & $1.642^{\mathrm{ab}}$ \\
\hline $\mathrm{C}-120 \mathrm{kcal} / \mathrm{kg}$ & 300 & $1.098^{b}$ & $1.381^{b}$ & $1.430^{\mathrm{b}}$ & $1.667^{a} \mathrm{~b}$ & $1.665^{\mathrm{ab}}$ & $1.911^{\mathrm{bc}}$ & $1.633^{c}$ \\
\hline $\mathrm{C}-120 \mathrm{kcal} / \mathrm{kg}$ & 400 & $1.074^{c}$ & $1.360^{c}$ & $1.422^{c}$ & $1.657^{\mathrm{abc}}$ & $1.657^{b}$ & $1.911^{b c}$ & $1.626^{\mathrm{cb}}$ \\
\hline SEM & & 0.004 & 0.003 & 0.003 & 0.009 & 0.004 & 0.006 & 0.003 \\
\hline$P$-value & & 0.0044 & 0.0001 & 0.0001 & 0.0006 & 0.0051 & 0.0437 & 0.0149 \\
\hline
\end{tabular}

a-e Means within a column with no common superscript differ significantly $(p<0.05)$.

${ }^{1}$ Means of 10 replicates of 25 birds per treatment.

${ }^{2} \alpha$-amylase $+\beta$-glucanase complex is produced by Bacillus amyloliquefaciens having a minimum activity of 200 kilo-Novo $\alpha$-amylase units and 350 fungal $\beta$-glucanase units per gram obtained from Novozymes A/S (Bagsvaerd, Denmark).

${ }^{3}$ Corrected for the weight of dead birds.

The use of $\alpha$-amylase as part of an enzyme blend that also contained beta-glucanase and xylanase increased the AME content of a corn-soy broiler diet, as well as apparent and true ileal amino acid digestibility of all amino acids (Rutherfurd et al., 2007). In the present study, field performance obtained with the diets with reduced energy and supplemented with an $\alpha$-amylase- $\beta$-glucanase complex was improved, albeit not completely compensating for the performance losses induced by the reduction of $120 \mathrm{kcal} / \mathrm{kg}$ in a dietary feeding program fed to $40 \mathrm{~d}$. The enzyme complex utilized in the current study has $\alpha$-amylase and $\beta$-glucanase activities. Corn-soy diets have small contents of $\beta$-glucans, estimated as $0.1 \%$ in corn and $0.3 \%$ in soybean meal (Gracia et al., 2003; Choct \& Annison, 1990). However, even though improvements due the action of $\alpha$-amylase on starch seem more likely because of the higher proportion of starch in 
Table 4 - Regression equations of BWG and FCR as AME was reduced and relative AME equivalence estimates with the supplementation of an $\alpha$-amylase $+\beta$-glucanase complex in the feeds from d 1 to 40 .

\begin{tabular}{|c|c|c|c|c|c|c|}
\hline \multirow{2}{*}{ Item } & \multirow{2}{*}{ Regression Equations } & \multirow{2}{*}{$r^{21}$} & \multirow{2}{*}{$P$-value } & \multicolumn{3}{|c|}{ Relative bioequivalence $\left(\mathrm{kcal} / \mathrm{kg} \mathrm{AME} \mathrm{n}^{2}\right.$} \\
\hline & & & & 200 mg/kg & $300 \mathrm{mg} / \mathrm{kg}$ & $400 \mathrm{mg} / \mathrm{kg}$ \\
\hline \multicolumn{7}{|l|}{ BWG, g } \\
\hline 1 to $7 \mathrm{~d}$ & $Y=-0.00005 x+0.1203$ & 0.1851 & 0.0056 & 6 & 6 & 6 \\
\hline 8 to $14 \mathrm{~d}$ & $Y=-0.00010 x+0.2931$ & 0.1778 & 0.0067 & 9 & 11 & 61 \\
\hline 15 to $21 \mathrm{~d}$ & $Y=-0.00019 x+0.5245$ & 0.3109 & 0.0002 & 55 & 61 & 55 \\
\hline 22 to $28 d$ & $Y=-0.00010 x+0.2931$ & 0.2126 & 0.0028 & 95 & 85 & 100 \\
\hline 29 to $35 d$ & $Y=-0.00010 x+0.2931$ & 0.1138 & 0.0332 & 48 & 65 & 70 \\
\hline 1 to $40 \mathrm{~d}$ & $Y=-0.00088 x+3,1523$ & 0.4218 & 0.0001 & 40 & 46 & 56 \\
\hline \multicolumn{7}{|l|}{ FCR } \\
\hline 1 to $7 \mathrm{~d}$ & $Y=0.00025 x+1.0835$ & 0.1128 & 0.0341 & 50 & 38 & 58 \\
\hline 8 to $14 d$ & $Y=0.00046 x+1.3486$ & 0.3063 & 0.0002 & 25 & 70 & 94 \\
\hline 15 to $21 \mathrm{~d}$ & $Y=0.00048 x+1.3903$ & 0.4643 & 0.0001 & 66 & 82 & 91 \\
\hline 22 to $28 d$ & $Y=0.00031 x+1.6257$ & 0.1732 & 0.0076 & 100 & 133 & 149 \\
\hline 35 to $40 \mathrm{~d}$ & $Y=0.00032 x+1.9050$ & 0.0983 & 0.0488 & 19 & 53 & 53 \\
\hline 1 to $40 \mathrm{~d}$ & $Y=0.00039 x+1.6035$ & 0.2891 & 0.0003 & 58 & 76 & 99 \\
\hline
\end{tabular}

${ }^{1}$ Coefficient of determination $\left(r^{2}\right)$ was obtained using data from all replicates.

${ }^{2}$ Determined based on response of the means to graded reduction of AME for each parameter. The relative bioequivalence was determined using the difference between the levels of $\operatorname{AME}(0,60,90$ and $120 \mathrm{kcal} / \mathrm{kg})$.

the compared with $\beta$-glucans, effects on the latter cannot be dismissed. Usually referred as having a highly negative impact on chicken performance due to their influence on gut content viscosity, $\beta$-glucans are usually considered an important anti-nutrient in diets containing rye, barley, or wheat. The contents of $\beta$-glucans $(1.2 \%$ in rye, $7.6 \%$ in barley, and $0.7 \%$ in wheat) are low compared to their disproportional negative impact on poultry performance (Annison,
1991; Maisonnier et al., 2001). Therefore, it possible that, despite in smaller proportions than in rye, barley and wheat, there may be a detectable impact of $\beta$-glucanase in corn-soy diets.

Since soybean meal is almost devoid of starch (Meng \& Slominski, 2005), the bulk of the starch in the diets utilized in the current study derived from corn. Based on published data (De Blas et al., 1999), the proportion of starch in the diets with $120 \mathrm{kcal}$ AME/kg reduction

Table 5 - Carcass, abdominal fat, and commercial cuts yields of broilers fed diets with graded AME reductions and supplemented or not with an $\alpha$-amylase $+\beta$-glucanase complex from d 1 to $40, \%$.

\begin{tabular}{lcccccc}
\hline Treatments & Enzyme, $\mathrm{mg} / \mathrm{kg}^{2}$ & Carcass & Abdominal fat & Breast meat & Leg quarters & Wings \\
\hline Control (C) & & 77.9 & $1.83^{\mathrm{ab}}$ & 31.9 & 32.7 & 10.0 \\
\hline $\mathrm{C}-60 \mathrm{kcal} / \mathrm{kg}$ & - & 77.5 & $1.73^{\mathrm{ab}}$ & 31.6 & 32.6 & 10.1 \\
\hline $\mathrm{C}-90 \mathrm{kcal} / \mathrm{kg}$ & - & 77.4 & $1.84^{\mathrm{ab}}$ & 32.2 & 32.5 & 10.2 \\
\hline $\mathrm{C}-120 \mathrm{kcal} / \mathrm{kg}$ & - & 77.7 & $1.90^{\mathrm{a}}$ & 32.0 & 32.3 & 10.2 \\
\hline $\mathrm{C}-120 \mathrm{kcal} / \mathrm{kg}$ & 200 & 77.6 & $1.79^{\mathrm{ab}}$ & 32.2 & 32.3 & 32.5 \\
\hline $\mathrm{C}-120 \mathrm{kcal} / \mathrm{kg}$ & 300 & 77.6 & $1.79^{\mathrm{ab}}$ & 32.0 & 32.6 & 10.1 \\
\hline $\mathrm{C}-120 \mathrm{kcal} / \mathrm{kg}$ & 400 & 77.4 & $1.67^{\mathrm{b}}$ & 31.8 & 0.2 \\
\hline SEM 1 & & 0.110 & 0.019 & 0.086 & 0.063 & 0.026 \\
\hline$P$-value & & 0.8589 & 0.0346 & 0.4375 & 0.5509 & 0.2351 \\
\hline
\end{tabular}

a-b Means with a column with no common superscript differ significantly $(p<0.05)$.

${ }^{1}$ Means of 10 replicates of 25 birds per treatment.

${ }^{2} \alpha$-amylase $+\beta$-glucanase complex is produced by Bacillus amyloliquefaciens having a minimum activity of 200 kilo-Novo $\alpha$-amylase units and 350 fungal $\beta$-glucanase units per gram obtained from Novozymes A/S (Bagsvaerd, Denmark). 
was estimated as increasing from $33.6 \%$ in the pre starter to $43.3 \%$ in the finisher diets. As shown in Table 3 , improvements in performance were mostly evident as birds aged, indicating that the supplementation with the enzyme complex was more beneficial when birds were fed diets with higher proportions of starch. Starch digestibility was evaluated in the current trial; however, BWG and FCR consistently improved in birds fed the enzyme complex as starch increased as part of total daily intake. Therefore, improvements in starch digestibility and higher glucose availability, which was eventually utilized as energy, may have been generated by the $\alpha$-amylase present in the enzymatic complex supplemented. Starch digestibility in poultry is typically considered high. For instance, Weurding et al. (2001) and Plavnik \& Sklan (1995) found $97.4 \%$ and $97.3 \%$ starch digestibility using different evaluation methods. However, Noy \& Sklan (1995) reported that cornstarch digestibility at the terminal ileum was as low as $85 \%$ and did not seem to increase with chicken age. Starch that escapes digestion in the small intestine, which is sometimes referred as resistant starch, may present an opportunity for the utilization of an exogenous $\alpha$-amylase (Plavnik \& Sklan, 1995). Chickens adapt well to starch-based diets (Svihus, 2011); therefore; the very high feed intake of the modern fast-growing broiler chickens may present physiological limitations for starch digestion, leaving part of the dietary starch undigested and available to react with a supplemental amylase.

Broiler performance improvements have been demonstrated with the use of many enzyme blends in a large range of environments and with feeds with very diverse ingredient composition. Based on the results of the present study, the dietary addition of the $\alpha$-amylase- $\beta$-glucanase complex evaluated seems to be an alternative in the field of additives that may potentially improve energy utilization by broiler chickens.

\section{CONCLUSIONS}

The commercial $\alpha$-amylase- $\beta$-glucanase complex tested in the present study had a beneficial impact on the BWG and FCR of broilers fed corn-soy diets. A reduction in abdominal fat was observed when $400 \mathrm{~g} /$ ton were supplemented to diets with $120 \mathrm{kcal}$ AME/kg reduction. Apparent metabolizable energy estimates based on the improvements observed in BWG and FCR were of 49,61 , and 78 for 200, 300 and $400 \mathrm{~g} /$ ton of the enzyme complex, respectively.

\section{AKNOWLEDGEMENTS}

S.L. Vieira received a research grant from the Conselho Nacional de Pesquisa (CNPq), Brazil.

The authors acknowledge the partial funding from DSM Nutritional Products.

\section{REFERENCES}

Adedokun SA, Sands JS, Adeola O. Determining the equivalent phosphorus released by an Escherichia coli-derived phytase in broiler chicks. Canadian Journal of Animal Science 2004;84:437-444.

Annison G. Relationship between the levels of non-starch polysaccharides and the apparent metabolizable energy of wheat assayed in broiler chickens. Journal of Agricultural and Food Chemistry 1991;39:12521256.

Bedford MR, Classen HL, Campbell GL. The effect of pelleting, salt and pentosanase on the viscosity of intestinal contents and the performance of broilers fed rye. Poultry Science 1991;70:1571-1577.

Café MB, Borges CA, Fritts CA, Waldroup PW. Avizyme improves performance of broilers fed corn-soybean meal-based diets. Journal Applied Poultry Research 2002;11:29-33

Choct M, Annison G. Anti-nutritive activity of wheat pentosans in broiler diets. British Poultry Science 1990;31:811-821.

Cowieson AJ, Bedford MR, Ravindran V. Interactions between xylanase and glucanase in maize-soy-based diets for broilers. British Poultry Science 2010;51:246-257.

De Blas C, Mateos GG, García-Rebollar P. Tablas FEDNA de composición y valor nutritivo de alimentos para la fabricación de piensos compuestos. Madrid: Fundácion Espanhola para el Desarollo de la Nutrición Animal; 1999.

Douglas MW, Parsons CM, Bedford MR. Effect of various soybean meal sources and Avizyme on chick growth performance and ileal digestible energy. Journal Applied Poultry Research 2000;9:74-80.

Englyst $\mathrm{H}$. Classification and measurement of plant polysaccharides. Animal Feed Science and Technology 1989;23:27-42.

FEDNA. Tablas FEDNA de composición y valor nutritivo de alimentos para la fabricación de piensos compuestos. $2^{\text {nd }}$ ed. Madrid: Fundación Española para el Desarrollo de la Nutrición Animal; 2003.

Gracia Ml, Araníbar MJ, Lázaro R, Medel P, Mateos GG. o-Amylase supplementation of broiler diets based on corn. Poultry Science 2003;82:436-442.

Jendza JA, Dilger RN, Sands JS, Adeola O. Efficacy and equivalence of an Escherichia coli-derived phytase for replacing inorganic phosphorus in the diets of broiler chickens and young pigs. Journal of Animal Science 2006;84:3364-3374.

Jozefiak D, Ptak A, Kaczmarek S, Ma $\square$ kowiak P, Sassek M, Slominski BA. Multi-carbohydrase and phytase supplementation improves growth performance and liver insulin receptor sensitivity in broiler chickens fed diets containing full-fat rapeseed. Poultry Science 2010;89:1939-1946.

Lázaro R, Gracia M, Medel P, Mateos GG. Influence of enzymes on performance and digestive parameters of broilers fed rye-based diets. Poultry Science 2003;82:132-140.

Leslie MA, Moran Jr. ET, Bedford MR. The effect of phytase and glucanase on the ileal digestible energy of corn and soybean meal fed to broilers. Poultry Science 2007;86:2350-2357. 
Maisonnier S, Gomez J, Chagneau AM, Carre B. Analysis of variability in nutrient digestibilities in broiler chickens. British. Poultry Science 2001;42:70-76.

Meng $X$, Slominski BA. Nutritive values of corn, soybean meal, canola meal, and peas for broiler chickens as affected by a multicarbohydrase preparation of cell wall degrading enzymes. Poultry Science 2005;84:1242-1251.

Noy $Y$, Sklan D. Digestion and absorption in the young chick. Poultry Science 1995;74:366-373.

Olukosi OA, Adeola O. Whole body nutrient accretion, growth performance and total tract nutrient retention responses of broilers to supplementation of xylanase and phytase individually or in combination in wheat-soybean meal based diets. Journal of Animal Science 2008;45:192-198.

Onderci M, Sahin N, Sahin K, Cikim G, Aydín A, Ozercan I, et al. Efficacy of supplementation of $\alpha$-amylase-producing bacterial culture on the performance, nutrient use, and gut morphology on broiler chickens fed a corn-based diet. Poultry Science 2006;85:505-510.

Petterson D, Graham H, Aman P. The nutritive value for broiler chickens of pelleting and enzyme supplementation of a diet containing barley, wheat and rye. Animal Feed Science and Technology 1991;33:1-14.

Plavnik I, Sklan D. Nutritional effects of expansion and short time extrusion on feeds for broilers. Animal Feed Science and Technology 1995;55:247-251.

Rostagno HS, Albino LFT, Donzele JL, Gomes PC, Oliveira RF, Lopes DC, et al. Tabelas brasileiras para aves e suínos. Composição de alimentos e exigências nutricionais $3^{\text {rd }}$ ed. Viçosa: UFV; 2011

Rutherfurd SM, Chung TK, Mounghan PJ. The effect of a commercial enzyme preparation on apparent metabolizable energy, the true ileal amino acid digestibility, and endogenous ileal lysine losses in broiler chickens. Poultry Science 2007;86:665-672.
Statistical Analisys System. SAS User's guide: statistics. $9^{\text {th }}$ ed. Cary: Institute Incorporation; 2009.

Svihus B. Limitations to wheat starch digestion in growing broiler chickens: a brief review. Animal Production Science 2011;51:583-589.

Tukey J. The philosophy of multiple comparisons. Statistical Science 1991;6:100-116

Veldman A, Vahl HA. Xylanase in broiler diets with differences in characteristics and content of wheat. British Poultry Science 1994;35:537-550.

Uni Z, Noy Y, Sklan D. Post hatch changes in morphology and function of the small intestines in heavy and light strain chicks. Poultry Science $1995 ; 74: 1622-1629$.

Weurding RE, Veldman A, Veen WAG, van der Aar PJ, Verstegen MWA In vitro starch digestion correlates well with rate and extent of starch digestion in broiler chickens. Journal of Nutrition 2001;131:23362342.

Vieira SL, Moran Jr. ET. Effects of egg of origin and chick post-hatch nutrition on broiler live performance and meat yields. World's Poultry Science Journal 1999;55:125-142.

Willamil J, Badiola I, Devillard E, Geraert PA, Torrallardona D. Wheatbarley-rye- or corn-fed growing pigs respond differently to dietary supplementation with a carbohydrase complex. Journal of Animal Science 2012;90:824-832.

Zanella I, Sakomura NK, Silversides FG, Fiqueirdo A, Pack M. Effect of enzyme supplementation of broiler diets based on corn and soybeans. Poultry Science 1999;78:561-568.

Zhou Y, Jiang Z, LV D, Wang T. Improved energy-utilizing efficiency by enzyme preparation supplement in broiler diets with different metabolizable energy levels. Poultry Science 2009;88:316-322. 
